Article

\title{
Low-cost Greenhouse Design for Sustainable Agricultural Pro- duction after COVID-19
}

\author{
Arnon Jumlongkul 1,*
}

1 School of Medicine, Mae Fah Luang University; arnon.jum@mfu.ac.th

* Correspondence: arnon.jum@mfu.ac.th; Tel.: +66-53-916-569

\begin{abstract}
This study aimed to focus on how to design a low-cost greenhouse for the cultivation of crops, to propose the cost-effectiveness analysis of small agribusiness, and to promote sustainable agricultural production during and after the COVID-19 crisis for helping grassroots and anyone who lost their job. This article is qualitative engineering research, studying of literature reviews of greenhouse farming concept and Micro, Small and Medium Enterprises, then, designing low-cost greenhouse model which was preliminarily adapted for hot climate countries. Three plants that were selected as representative plants of this model include sunflower, water spinach, and wheat. The greenhouse model, measuring $5 \times 7 \times 4 \mathrm{~m}(\mathrm{~W} \times \mathrm{L} \times \mathrm{H})$, was designed for this mission. The total cost of one building is approximately 97,994 THB. For the worthiness of the investment, farmers should build at least three greenhouse buildings, which will return total income to farmers approximately 34,666.09 THB per month. The suggestion includes further knowledge and financial supports from the government sectors among farmers, then, boost them up using high-level technology and also planting high-price agribusiness production to promote the local economy to be strong and sustainable.
\end{abstract}

Keywords: COVID-19; greenhouse; MSMEs; renewable energy; solar energy

\section{Introduction}

According to social distancing and lockdown policies during the COVID-19 pandemic, many economic and social systems have been directly affected. Prolonged mobility restrictions have inevitably damaged the global economy. The mobility prevention of individuals can reduce the disposable income between $-10 \%$ up to $-40 \%$ among both infected and non-infected workers in Italy following stop working [1]. A study showed world output fell by $-7 \%$ when only China declared a lockdown policy and reached $-23 \%$ after many countries were under a lockdown at the early time of crisis [2]. When considering the household income, for example, in the San Francisco Bay Area, the poverty rate increased from $17.1 \%$ up to $25.9 \%$ within three months while many developing countries in Southeast Asia, including Thailand, is predicted to decline gross domestic product (GDP) by $0.6 \%$ at the end of 2020 according to decrease in global trade, tourism, and investment [3]. The COVID-19 situation being has affected most all occupations, for example, a study in India showed the huge impact on multi-affected sectors, including, aviation, retail, capital market, tourism, and oil while Micro, Small and Medium Enterprises (MSMEs) have suffered from this severe cash crunch [4].

As part of agriculture, which is one of the most important sectors endorsing food security, the pandemic has interfered with the supply chain due to the lack of labor, production, and distribution company, especially in the crop, livestock, poultry, dairy, and fishery industries. According to the Chinese lockdown policy, global farmers have faced a shortage of initial agricultural production (e.g. seed, pesticide, manure, chemical fertilizer) for producing their agro products [5]. In China, crop production is mainly affected 
according to the impact of COVID-19. The government's immediate countermeasures included, for example, continuing agricultural production, resuming farmers' work, supporting financial grants, providing agriculture technology, and providing assistance to low-income farmers. However, those actions do not include all impact aspects [6]. Global agricultural markets also impact the decline in economic growth, including, the decrease of $7-18 \%$ and $4-7 \%$ of international meat prices as well as dairy products, strong falling of biofuel price followed by feedstock, maize, and oilseeds. However, global food consumption is still unaffected according to the inelastic agricultural commodity demand and the shortage period of the stock [7]. This situation is eventually identified as a gap for creating some agro products during the pandemic.

When considering the aspect of entrepreneurship, a study showed the result of surveying of more than 5,800 small businesses that mass layoffs and closures had occurred in a few weeks after the start of the COVID-19 pandemic. Many of them have faced financial fragility [8]. For sustaining enterprise operations during the COVID-19 crisis, the Enterprises Effectiveness and Sustainability Model during Pandemic suggested that companies should have distributed leadership, workforce, and adaptive culture. Moreover, resilient enterprises should provide more informed and decentralized decision-making. Online platforms, for example, social media, integrate intranet, and internet should amalgamate with daily business routines that can establish trust and bonds among all stakeholders [9]. The challenge is how to implement all those concepts to farmers, grassroots, or anyone who lost their job during this crisis.

As mentioned above, the objectives of this article are to design a low-cost greenhouse for the cultivation of crops, to propose the cost-effectiveness analysis of small agribusiness, and finally, to promote sustainable agricultural production during and after the COVID-19 crisis.

\section{Materials and Methods}

A case study was proposed by the microbusiness owner in Chiang Rai Province, Thailand, who joined the Pre-talent Mobility Project organized by Mae Fah Luang University. He raised his problem related to the lack of knowledge in his business and also budgets. His proposal has never overcome the financial institutional agreements. The preliminary analysis showed that he could not select the type of plant for cultivation within his greenhouse farming or plant factory appropriately, could not evaluate the break-even point (BEP) of his business, and could not select technology-enhanced productivity properly. To solve these problems, this article is qualitative research in engineering design. The scope of this study is to explore an optimal design of a low-cost greenhouse amalgamated with local renewable energy, to make informed business planning, and to create and maintain a sustainable business. Thailand was selected as a representative of hot climate agricultural developing countries. Some essential details are discussed below;

\subsection{Greenhouse concept}

Greenhouse farming is one of the agricultural systems that challenge mankind to produce world food supply sufficiently and sustainably in the twenty-first century. The global research trends in the field of greenhouse have focused on water and irrigation supply, the design of optimum greenhouse structure, soil conservation, energy use, climate control, and pest control. The challenge of this sector is the economic-financial feasibility among farmers, feedback loop between farmers and the needs of the sector, supportive systems from institutions or governments to farmers, and last, filling the gap between the technological knowledge and the end-users' tradition (10). In Thailand, a case study using the smart technology for the agricultural sector showed a closed-vertical farming system that was incorporated with artificial intelligence (AI) light, controlled environment (e.g. air conditioning system, humidity, CO2 concentration, nutrient solution), and the Internet of Things technologies. The project researchers claimed that they could produce approximately 50,552 lettuce heads per month within a plant factory, measuring 
$173.85 \mathrm{~m}^{2} \times 6 \mathrm{~m}$ in height (11). The concern of this issue is how to implement this modern farming concept into grassroots or anyone who has not a lot of money to provide highlevel technology such as Internet of Things and AI systems.

According to energy supply, in general, renewable energy (RE), for example, solar, wind, water, and biomass energy are defined as the common use of resources. These alternative resources have been selected to replace the use of fossil fuels (12). Among Southeast Asian Countries, ASEAN has set a policy for RE usage up to $23 \%$ by 2025 . In Thailand, there is a renewable energy consumption target rising to $30 \%$ as well as an electric vehicle (EV) will be enhanced to increase to 1.2 million EVs and 690 charging stations by 2036 (13). The optimum greenhouse design therefore should generate RE or use RE as part of this novel model to support mechanical as well as electric farming devices.

\subsection{Micro, Small and Medium Enterprises (MSMEs)}

Individual business or individuals that can carry out a small-scale community economic activity also called MSMEs, which is divided into three groups following the World Bank, including, Micro Business (employees limited to 10 people), Small Business (employees limited to 30 people), and Medium Business (employees limited to 300 people), respectively. To promote these business groups, some MSMEs owners believed that using Electronic Money (e-money) will help them receive performance gains (14). In food business sector, a study showed three dimensions, which have influenced in the digitalization era, include the changing of consumer consumption pattern, business competition, as well as business environment (15). In Thailand, the government declared the national development model, namely 'Thailand 4.0', which was adapted from the industry 4.0 concept. This model also has supported creativity and innovation among regional small firms or MSMEs to create their value-added businesses. A total of 2.8 million small firms was found in 2018. The integrative new idea generation, and market-leadership orientation, are two essential keys that can drive the strategic entrepreneurial awareness among Thai owners (16). Therefore, to promote the sustainability of MSMEs, especially in Thailand, all requirements from both owners and customers should be concerned.

\section{Results and discussion}

Analyzed data involve in this paper was surveyed from Thai online businesses, including, plant stores, building material stores, electronic shops, retail shops, greenhouse entrepreneurs, and also contractors. Assisted-decision making details are shown as follow;

\subsection{Plant product}

The market price of each plant is the most important factor which should be considered before preparing the cultivation. Some plant values that are lesser than 100 Thai Baht (THB)/kg should be avoided because in general, the minimum wage in Thailand is higher than 300 THB. Therefore, this situation can make business owners go broke according to the lack of competitiveness with the traditional cultivation. To prevent the effects of fluctuation of market price, three popular crops that are cultivated approximately 8 days per cycle, including, Helianthus or sunflower, Ipomoea aquatica or water spinach, and also wheat were selected as the model to explain this formulation. The value of sprout of each plant is approximately $100 \mathrm{THB} / \mathrm{kg}$. Table 1 shows the explanation of value analysis among three plants for one tray per cultivation cycle. 
Table 1. Comparison of value analysis of sunflower, water spinach, and wheat for one tray per cultivation cycle.

\begin{tabular}{|c|c|c|c|c|}
\hline \multirow[b]{2}{*}{ Item } & \multicolumn{3}{|c|}{ Plant } & \multirow[b]{2}{*}{ Unit } \\
\hline & Sunflower & Water spinach & Wheat & \\
\hline \multicolumn{5}{|l|}{ Cost } \\
\hline Seed/kg & $22.50^{*}$ & $17.50^{*}$ & $12.50^{1}$ & THB \\
\hline $30 \times 60 \mathrm{~cm}$ tray (50 THB/tray, use for 200 cycles) & 0.25 & 0.25 & 0.25 & THB \\
\hline Seedling media (1 THB/kg/tray, use for 3 cycles) & 0.33 & 0.33 & 0.33 & THB \\
\hline Commercial bag (170 THB/pack, 135 piece/pack) & 1.26 & 1.26 & 1.26 & THB \\
\hline Water $(1 \mathrm{THB} / 100 \mathrm{~L})$ & 1.00 & 1.00 & 1.00 & THB \\
\hline Total cost/tray & 25.34 & 20.34 & 15.34 & THB \\
\hline \multicolumn{5}{|l|}{ Sale price } \\
\hline $\begin{array}{l}\text { Wholesale price } 100 \mathrm{THB} / \mathrm{kg} \\
\text { (seed weight : sprout weight }=1: 4 \text { ) }\end{array}$ & 60.00 & 50.00 & 125.00 & THB \\
\hline \multicolumn{5}{|l|}{ Summary } \\
\hline Profit/tray & 34.66 & 29.66 & 109.66 & THB \\
\hline Cost $/ \mathrm{kg}$ & 42.24 & 40.69 & 61.37 & THB \\
\hline Cultivation cycle (day) & 8.00 & 8.00 & 8.00 & Day \\
\hline
\end{tabular}

${ }^{1}$ Where: sunflower seed $=150 \mathrm{THB} / \mathrm{kg}$, use $0.15 \mathrm{~kg} /$ tray; water spinach seed = $140 \mathrm{THB} / \mathrm{kg}$, use $0.125 \mathrm{~kg} /$ tray; wheat seed = $100 \mathrm{THB} / \mathrm{kg}$, use $0.125 \mathrm{~kg} /$ tray.

\subsection{Greenhouse model}

The greenhouse model, measuring $5 \times 7 \times 4 \mathrm{~m}(\mathrm{~W} \times \mathrm{L} \times \mathrm{H})$, was designed for this mission. For the worthiness of the investment, farmers should build at least three greenhouse buildings. Therefore, only $150 \mathrm{~m}^{2}$ of land (70\% greenhouse farming, and $30 \%$ multiuse space) is sufficient for operating this business. In the early business phase, farmers should not make any systems amalgamate with the Internet of Things technologies because they sometimes may not overcome the total cost of greenhouse farming. The appropriate energy resource of Thailand is solar energy, then, solar cells should be applied and amalgamated with provincial electricity for supporting any electrical system. The total cost of one building is approximately 97,994 THB. Cost analysis of greenhouse construction is shown in Table 2. The greenhouse model is shown in Figure 1, 2, 3, and 4. 
Table 2. Cost analysis of greenhouse construction.

\begin{tabular}{|c|c|c|}
\hline Item & Value & Unit \\
\hline $\begin{array}{l}\text { Greenhouse structure } 5 \times 7 \text { m } \\
\text { Greenhouse roofing plastic } \\
\text { Insect protection net } \\
\text { Galvanized steel pipe } \\
\text { Other materials }\end{array}$ & $38,500.00$ & THB \\
\hline $\begin{array}{l}\text { Cultivation table } \\
\text { Size } 0.7 \times 2.5 \times 1.3 \mathrm{~m}(\mathrm{~W} \times \mathrm{L} \times \mathrm{H}) \text { made of } 0.8 \text { inch galvanized } \\
\text { steel rectangular tube, } 1,900.00 \mathrm{THB} / \text { table } \times 5 \text { tables }\end{array}$ & $9,500.00$ & 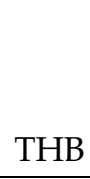 \\
\hline $\begin{array}{l}\text { Cooling system } \\
\text { Air cooling fan } 24 \mathrm{~V} 80 \mathrm{~W}, 12 \text { inch diameter, cover } 15 \mathrm{~m}^{2} / \text { piece, } \\
318.00 \mathrm{THB} / \text { set } \times 3 \text { sets }\end{array}$ & 954.00 & THB \\
\hline $\begin{array}{l}\text { Electrical support system } \\
\text { Polycrystalline solar panel } 340 \mathrm{~W}, 3,350.00 \mathrm{THB} / \text { set } \times 5 \text { sets }\end{array}$ & $16,750.00$ & THB \\
\hline $\begin{array}{l}\text { Light system } \\
\text { Phyto lamp LED Grow Light 30W AC 220V, } 366 \text { THB/set x } 3 \\
\text { sets/cultivation table }\end{array}$ & $5,490.00$ & THB \\
\hline $\begin{array}{l}\text { Electrical and water control systems } \\
\text { Safety breaker } 550.00 \mathrm{THB} \\
\text { Electric cable } 25.00 \mathrm{THB} / \mathrm{m} \times 50 \mathrm{~m} \\
\text { Digital timer } 1,000.00 \mathrm{THB} \\
\text { Set of water pipe } 1,000.00 \mathrm{THB} \\
\text { Set of electric box } 2,000.00 \mathrm{THB} \\
\text { Water pump 7,000.00 THB }\end{array}$ & $12,800.00$ & THB \\
\hline $\begin{array}{l}\text { Wages } \\
\text { Wage for water supply installation } \\
\text { Wage for solar cell installation } \\
\text { Wage for light system installation } \\
\text { Wage for electrical system installation }\end{array}$ & $14,000.00$ & THB \\
\hline Total cost & $97,994.00$ & THB \\
\hline
\end{tabular}




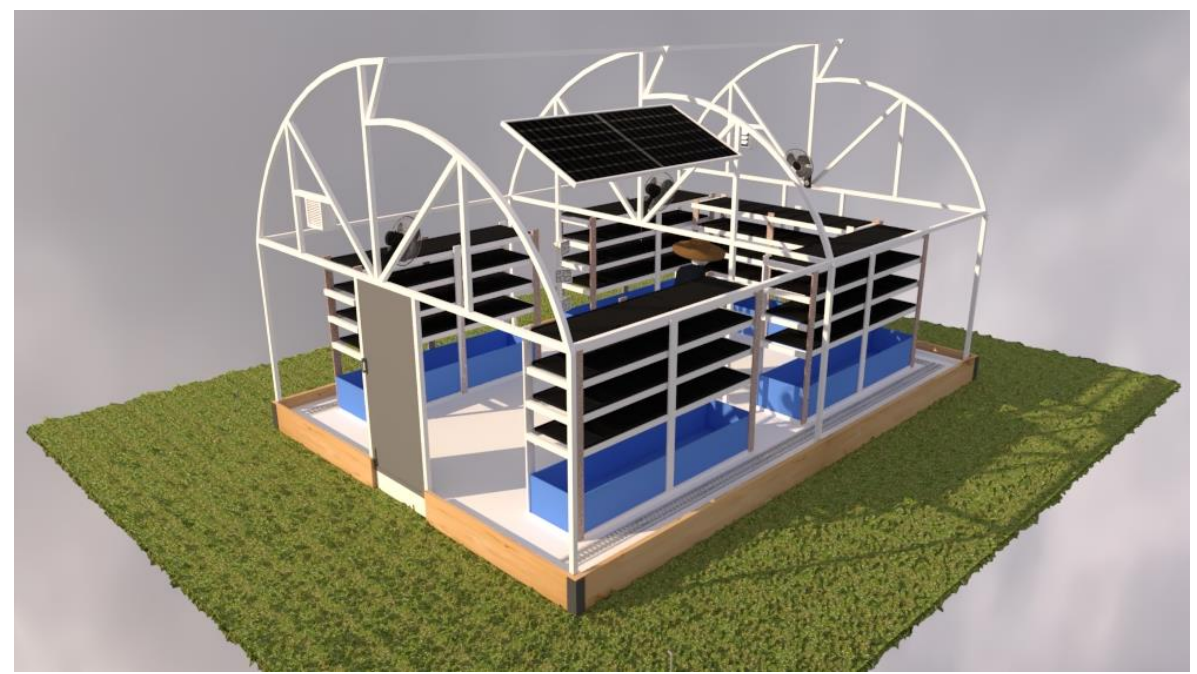

Figure 1. The overall view of greenhouse building.

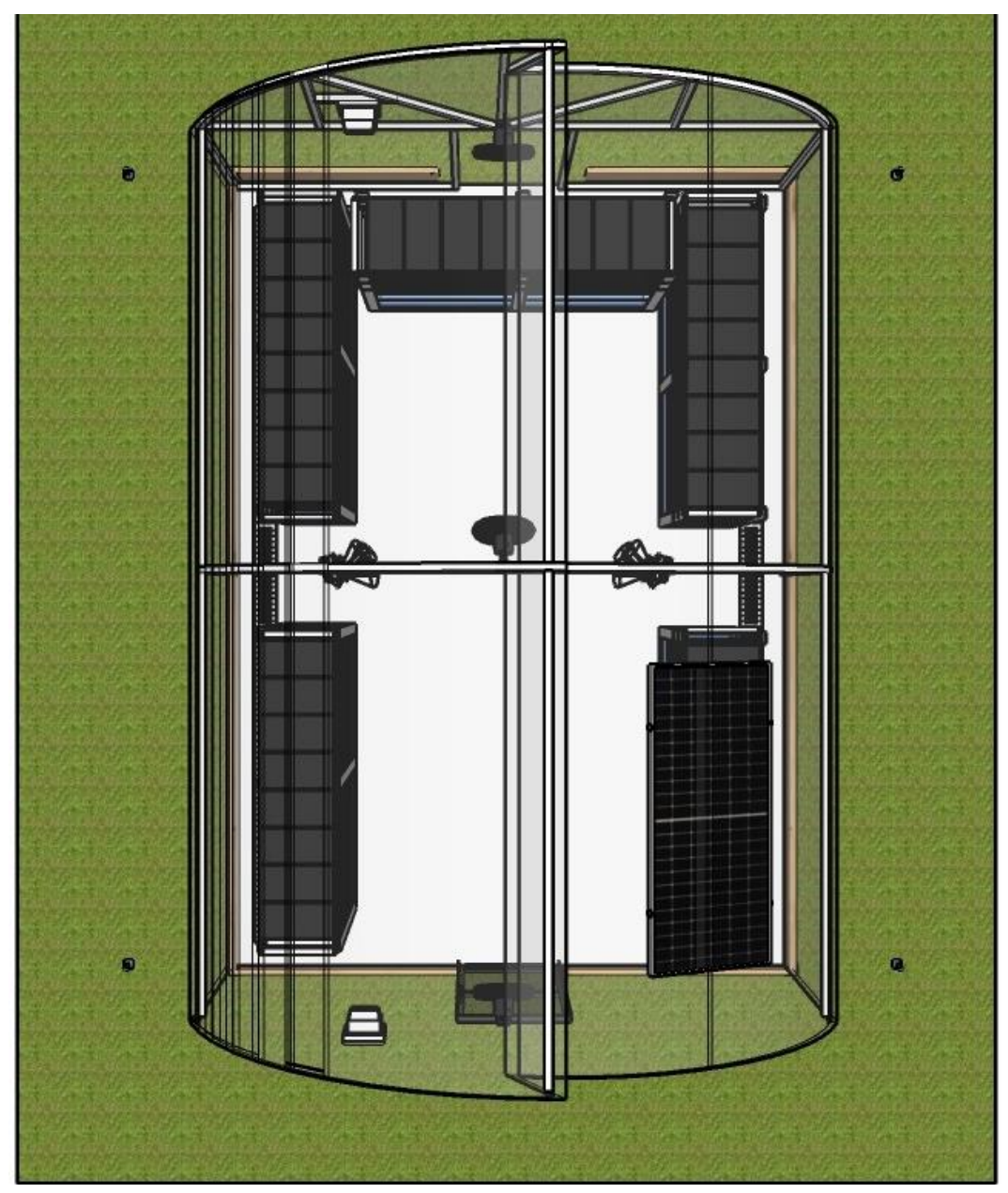

Figure 2. The top view of greenhouse building. 


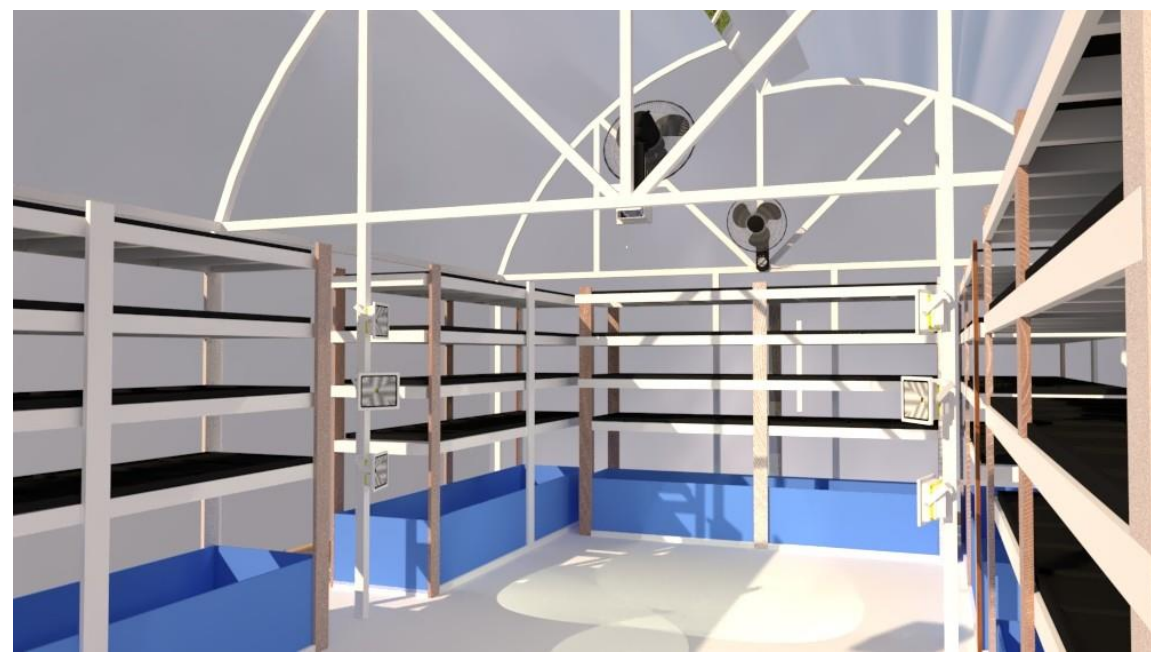

Figure 3. The detail of any materials position within the greenhouse building.

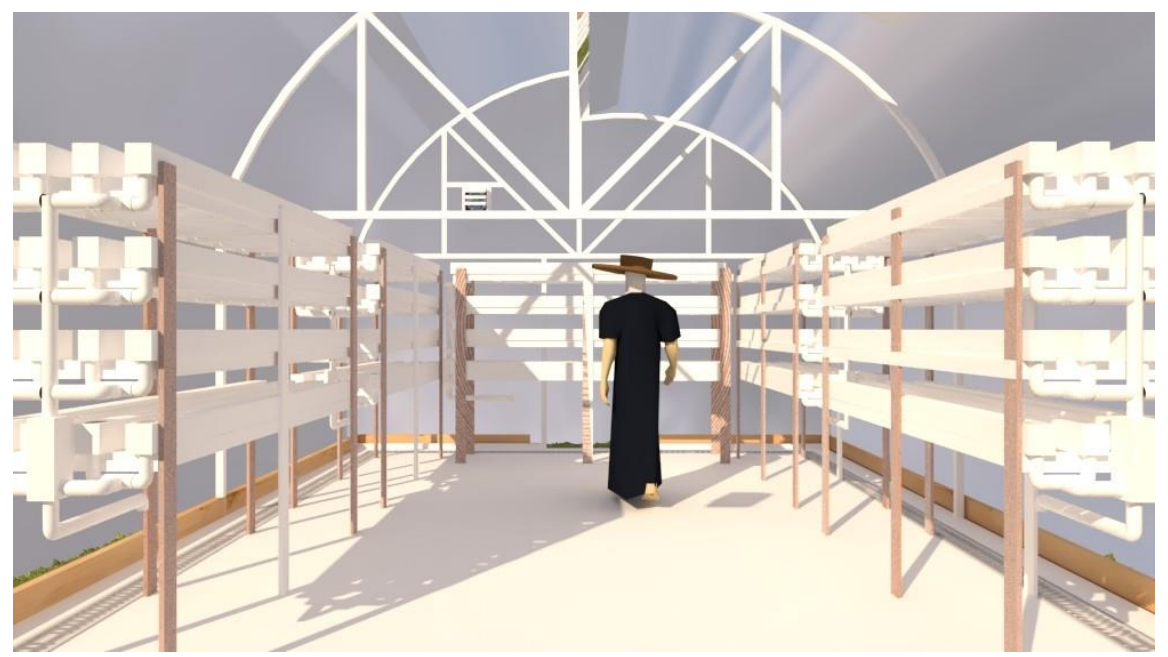

Figure 4. The inside view of greenhouse building.

\subsection{Cost-effective analysis}

In table 3, the comparison of income among one, three, and seven sunflower greenhouse buildings was calculated. Farmers should receive their wages of approximately 20,000 THB per month while employee wages should not be set lower than 300 THB per day. Profit will overcome total cost when the greenhouse construction is at least of three buildings that will return the net profit 14,666.09 THB with entrepreneurial wages 20,000 $\mathrm{THB}$, then, farmers will gain approximately 34,666.09 THB per month. If farmers extend the size of the building, then, the construction cost may decline approximately 5 to $20 \%$ according to reducing of metallic materials and also electrical systems. 
Table 3. Cost-effectiveness analysis of sunflower greenhouse farming.

\begin{tabular}{|c|c|c|c|c|}
\hline Item & \multicolumn{3}{|c|}{ Amount numeric } & Unit \\
\hline Greenhouse building & 1.00 & 3.00 & 7.00 & Building \\
\hline Cultivation table & 5.00 & 15.00 & 35.00 & Table \\
\hline Sunflower sprout & 160.00 & 480.00 & $1,120.00$ & Tray \\
\hline $\begin{array}{l}\text { Product per cycle } \\
\text { (seed weight : sprout weight }=1: 4 \text { ) }\end{array}$ & 96.00 & 288.00 & 672.00 & $\mathrm{~kg}$ \\
\hline $\begin{array}{l}\text { Transportation charge } \\
=800 \mathrm{THB} / \text { cycle, } \\
3 \mathrm{THB} / \mathrm{km} \text { for gas within } 200 \mathrm{~km} / \text { cycle, car } \\
\text { maintenance cost } 200 \mathrm{THB} / \text { cycle }\end{array}$ & 800.00 & $2,400.00$ & $5,600.00$ & THB \\
\hline $\begin{array}{l}\text { Maximum profit per cycle without } \\
\text { building cost and maintenance } \\
=\text { (net profit/tray } x \text { amount of tray) - } \\
\text { transportation charge }\end{array}$ & $4,745.19$ & $14,235.56$ & $33,216.30$ & $\mathrm{THB}$ \\
\hline $\begin{array}{l}\text { Maximum profit per year without } \\
\text { building cost and maintenance } \\
\text { ( } 352 \text { workdays/year, } 13 \text { holidays/year) }\end{array}$ & $208,788.15$ & $626,364.44$ & $1,461,517.04$ & THB \\
\hline $\begin{array}{l}\mathbf{5 \%} \text { damage value per year } \\
\text { (ungrowth plant or retardation) }\end{array}$ & $10,439.41$ & $31,318.22$ & $73,075.85$ & THB \\
\hline $\begin{array}{l}\text { Depreciation of building per year } \\
\text { (working life of greenhouse }=7 \text { years) }\end{array}$ & $13,999.14$ & $41,997.43$ & $97,994.00$ & THB \\
\hline $\begin{array}{l}\text { Electricity charge per year }{ }^{1} \\
\text { (if use a dual system between solar cell and } \\
\text { local electricity) }\end{array}$ & $5,263.00$ & $15,789.00$ & $36,841.00$ & THB \\
\hline $\begin{array}{l}\text { Employee wages per year } \\
=300 \mathrm{THB} / \text { person/day, } \\
13 \text { holidays/year, } 1 \text { laborer can manage at } \\
\text { least } 7 \text { buildings/day }\end{array}$ & $105,600.00$ & $105,600.00$ & $105,600.00$ & THB \\
\hline $\begin{array}{l}\text { Entrepreneurial wages per year } \\
=20,000 \mathrm{THB} / \text { month }\end{array}$ & $240,000.00$ & $240,000.00$ & $240,000.00$ & THB \\
\hline $\begin{array}{l}\text { Depreciation of instrument per year } \\
\text { Container gardening 3,000 THB } \\
\text { Cart 6,000 THB } \\
\text { Sprout cutting machine 30,000 THB } \\
\text { Agricultural instruments 8,000 THB } \\
=47,000 \mathrm{THB} / 3 \text { years } \\
\text { (working life of any instruments = } 3 \text { years) }\end{array}$ & $15,666.67$ & $15,666.67$ & $15,666.67$ & THB \\
\hline
\end{tabular}




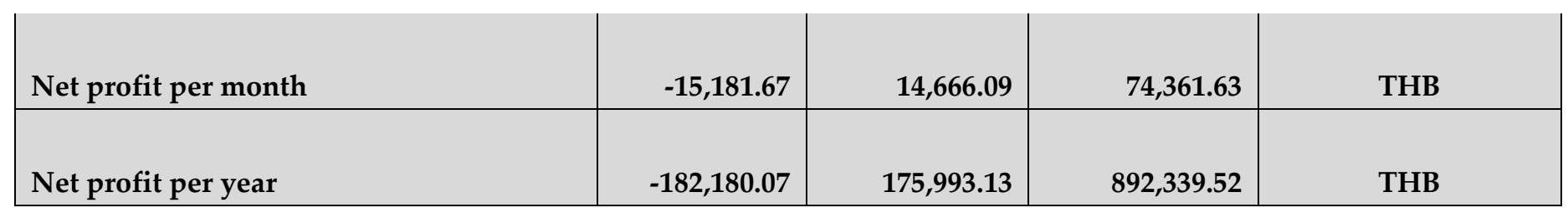

${ }^{1}$ Where: working time $=10 \mathrm{~h} /$ day; LED $30 \mathrm{~W} \times 10 \mathrm{~h} \times 3$ sets/table $\times 5$ tables/building $\times 30$ days/month $=135 \mathrm{~kW}$, then, $135 \mathrm{~kW} \times 3.2484 \mathrm{THB} / \mathrm{kW} \cdot \mathrm{h}=438 \mathrm{THB} /$ month or $5,263 \mathrm{THB} /$ year.

The low-cost greenhouse model, which is proposed in this paper, can be built immediately. However, the investment fund for grassroots or farmers is the most important challenge in this situation. To overcome this moment, the governments or academic institutes should coach the concept of greenhouse farming, principle of business and e-commerce, proposal writing, and boost up plant entrepreneurs to help them pass the financial institution agreements. Moreover, after farming establishment, they also need to prolong support until they can extend their business up to at least small enterprises to make sure that they can stand solely. After becoming of business strength, high-level technology (e.g. Internet of Things, plant factory, artificial intelligence systems), as well as high agribusiness plant (e.g. medicinal plant, biomaterials) that need high standard protective systems, should be put forward to elevate the business scale to promote agricultural sustainability for a new future.

\section{Conclusions}

In summary, lockdown policies in many countries have made the collapse of MSMEs during this COVID-19 pandemic. The mobility restrictions have affected multi-sectors and also labor and agricultural systems. This article was developed for helping farmers, grassroots, as well as anyone who lost their job through the plant business using low-cost greenhouse farming. Information within this paper also involves how to select appropriate plants, greenhouse farming prototype, and cost-effectiveness of the number of greenhouse building. The suggestion includes further knowledge and financial supports from the government sectors among farmers. In the future, plant business owners can scale up their firm using high-level technology and also planting high-price agribusiness production. The author hopes this model can generate ideas among many people who have suffered from the economic crisis, and also enhance the local economy to be strong and sustainable.

Supplementary Materials: The following are available online at www.mdpi.com/xxx/s1, Figure 1: the overall view of greenhouse building, Figure 2: The top view of greenhouse building, Figure 3: the detail of any materials position within the greenhouse building, Figure 4: the inside view of greenhouse building, Table 1: comparison of value analysis of sunflower, water spinach, and wheat for one tray per cultivation cycle, Table 2: cost analysis of greenhouse construction, Table 3: costeffectiveness analysis of sunflower greenhouse farming.

Author Contributions: A.J. created this work solely.

Funding: This work was supported by the Mae Fah Luang University Intellectual Property and Innovation Management Division [Pre-talent Mobility Project, grant numbers 7742(2)/1544, fiscal year 2020].

Data Availability Statement: excluded.

Acknowledgments: Special thanks to Mr. Watchara Jamnuch, an electrical engineer, for technical support and also Dr. Roger Timothy Callaghan, School of Medicine, Mae Fah Luang University for grammatical approval.

Conflicts of Interest: The authors declare no conflict of interest. 


\section{References}

1. Spelta A, Flori A, Pierri F, Bonaccorsi G, Pammolli F. After the lockdown: simulating mobility, public health and economic recovery scenarios. Sci Rep [Internet]. 2020 Dec [cited 2020 Dec 20];10(1). Available from: http://www.nature.com/articles/s41598-020-73949-6

2. Mandel A, Veetil V. The Economic Cost of COVID Lockdowns: An Out-of-Equilibrium Analysis. Econ Disasters Clim Change. 2020 Oct;4(3):431-51.

3. Martin A, Markhvida M, Hallegatte S, Walsh B. Socio-Economic Impacts of COVID-19 on Household Consumption and Poverty. Econ Disasters Clim Change. 2020 Oct;4(3):453-79.

4. Chaudhary M, Sodani PR, Das S. Effect of COVID-19 on Economy in India: Some Reflections for Policy and Programme. J Health Manag. 2020 Jun;22(2):169-80.

5. Bahadur Poudel P, Ram Poudel M, Gautam A, Phuyal S, Krishna Tiwari C, Bashyal N, et al. COVID-19 and its Global Impact on Food and Agriculture. J Biol Todays World. 2020;9(5):1-4.

6. Pan D, Yang J, Zhou G, Kong F. The influence of COVID-19 on agricultural economy and emergency mitigation measures in China: A text mining analysis. Xue B, editor. PLOS ONE. 2020 Oct 23;15(10):e0241167.

7. Elleby C, Domínguez IP, Adenauer M, Genovese G. Impacts of the COVID-19 Pandemic on the Global Agricultural Markets. Environ Resour Econ. 2020 Aug;76(4):1067-79.

8. Bartik AW, Bertrand M, Cullen Z, Glaeser EL, Luca M, Stanton C. The impact of COVID-19 on small business outcomes and expectations. Proc Natl Acad Sci. 2020 Jul 28;117(30):17656-66.

9. Obrenovic B, Du J, Godinic D, Tsoy D, Khan MAS, Jakhongirov I. Sustaining Enterprise Operations and Productivity during the COVID-19 Pandemic: “Enterprise Effectiveness and Sustainability Model”. Sustainability. 2020 Jul 24;12(15):5981.

10. Aznar-Sánchez JA, Velasco-Muñoz JF, López-Felices B, Román-Sánchez IM. An Analysis of Global Research Trends on Greenhouse Technology: Towards a Sustainable Agriculture. Int J Environ Res Public Health. 2020 Jan 20;17(2):664.

11. Santiteerakul S, Sopadang A, Yaibuathet Tippayawong K, Tamvimol K. The Role of Smart Technology in Sustainable Agriculture: A Case Study of Wangree Plant Factory. Sustainability. 2020 Jun 5;12(11):4640.

12. Qazi A, Hussain F, Rahim NABD, Hardaker G, Alghazzawi D, Shaban K, et al. Towards Sustainable Energy: A Systematic Review of Renewable Energy Sources, Technologies, and Public Opinions. IEEE Access. 2019;7:63837-51.

13. Erdiwansyah, Mamat R, Sani MSM, Sudhakar K. Renewable energy in Southeast Asia: Policies and recommendations. Sci Total Environ. 2019 Jun;670:1095-102.

14. Gunawan H, Sinaga BL, Wp SP. Assessment of the Readiness of Micro, Small and Medium Enterprises in Using E-Money Using the Unified Theory of Acceptance and Use of Technology (UTAUT) Method. Procedia Comput Sci. 2019;161:316-23.

15. Fauzi AA, Sheng ML. The digitalization of micro, small, and medium-sized enterprises (MSMEs): An institutional theory perspective. J Small Bus Manag. 2020 Aug 19;1-26.

16. Sriboonlue P, Puangpronpitag S. Towards Innovative SMEs: An Empirical Study of Regional Small and Medium Enterprises in Thailand. Procedia Comput Sci. 2019;158:819-25. 